DOI: $\underline{10.35619 / \text { iiu.v1i14.406 }}$

Грубляк Вячеслав

кандидат медичних наук, доцент

Кам'янець-Подільського національного університету імені Івана Огієнка,

м. Кам'янець-Подільський, Україна

ORCID: 0000-0001-8690-4227

e-mail: sladoc15@gmail.com

\title{
ВАРІАТИВНИЙ ВПЛИВ ХРОНІЧНОЇ СОМАТИЧНОЇ ПАТОЛОГІЇ НА ПСИХОЕМОЦІЙНИЙ СТАН ЮНАКІВ І ПІДЛІТКІВ У ПРОЦЕСІ НАВЧАННЯ
}

\begin{abstract}
Анотація. Стаття присвячена з'ясуванню негативного впливу соматичної патології на психоемоційний стан юнаків і підлітків, пріоритетним напрямами психологічної корекції. Дослідження мало за мету вивчити вплив хронічних захворювань на психологічний стан i загальний розвиток особистості юнаків і підлітків, зміну поведінки та сприйняття, з'ясувати домінуючі соматичні та психологічні наслідки в процесі навчання. Були визначені основні завдання та напрями психокорекційної роботи 3 юнаками та підлітками при хронічних соматичних захворюваннях. Підтверджена необхідність поглиблення пізнавальних процесів підлітків, корекції поведінки та психоемоційного розвитку; вдосконалення навичок емоційно-особистісної саморегуляції, профорієнтаційної спрямованості, навичок спілкування і комунікативної компетентності, світоглядних установок. На основі емпіричного дослідження виділено пріоритетні напрями психокорекційної роботи, розроблені пропозиції щодо зменшення негативного впливу соматичної патології на їх психоемоційний стан юнаків та підлітків. Особливе значення в соціальній реадаптації юнаків і підлітків, відновленні фізичної активності та навчальних здібностей приділяється психокорекції, консультуванню, досягненню певного рівня емпатії, психоемоційній підтримці, супроводу та динамічному моніторингу симптомів після загострень хронічних соматичних захворювань.
\end{abstract}

Ключові слова: соматичні захворювання, психокорекційна робота, реадаптація.

Постановка проблеми. В підлітковому та юнацькому віці соматична патологія має особливе значення внаслідок негативного впливу на сприйняття та поведінку під час навчання та здобуття професійних навичок. До того ж на перше місце нерідко виходить суб'єктивне переживання хвороби. Хронічні захворювання внутрішніх органів або 


\section{Інноватика у вихованні. Випуск 14. 2021.}

фізичні вади мають до $10 \%$ підлітків, які впродовж тривалого часу можуть впливати на загальний розвиток особистості (Фетискин, Козлов та Мануйлов, 2002; Wegner, 2000). Щодо юнацького віку, то цей показник у студентів коливається від 4 до 6\%. Найчастіше - це захворювання з легким перебігом (Eurenius, Brodin, Lindblad, 2007). Але навіть при тривалій компенсації соматичні симптоми істотно погіршують якість життя, час від часу призводять до тимчасової втрати працездатності, зміни поведінкових реакцій та адаптації під час навчання, а також негативного впливу на особистість, спричиненого хронічним патологічним процесом та усвідомлення цієї причини (Alonso, Angermeyer, Bernert, Bruffaerts, Brugha, Bryson, 2004).

Аналіз останніх досліджень 3 проблеми. Поширеність психоемоційних розладів 3 соматичними симптомами у загальній популяції становить 5-7 \% (Bagayogo, Interian \& Escobar, 2013). Ще в 1898 році А. Гольдшейдер, а пізніше й К. Ясперс запропонували розділяти аутоi алопластичну картини захворювання. Суб'єктивне переживання хвороби отримало назву аутопластичної картини захворювання як продукту пізнання та усвідомлення індивідуумом змін свого стану, в структурі якої виділяють такі компоненти:

1) сенситивний - вплив локального болю за законом розповсюдження імпульсів 3 більш периферичних до центральних відділів нервової системи;

2) емоційний - страх, тривога, відчай , надія та інші емоційні переживання;

3) вольовий - зусилля подолати хворобу, подбати про обстеження;

4) раціональний (інформативний) - інформованість про захворювання, намагання адаптувати свої можливості під перебіг захворювання (Винника та Вітенко, 2006; Wegner, 2000).

Ці аспекти аутопластичної картини є тісно переплетені між собою в різних комбінаціях, через що виділяють такі типи ставлення особистості до хронічного внутрішнього захворювання:

1) нормальне (адекватне до стану хворого та інформації про хворобу);

2) зневажливе (недооцінка хвороби, нехтування лікуванням, безпідставний оптимізм);

3) заперечуюче (заперечення думки про хворобу, уникнення лікування);

4) нозофобне (страх хвороби, безпідставне багаторазове обстеження);

5) іпохондричне (впевненість у наявності тяжкого захворювання);

6) нозофільне (заспокоєння внаслідок отримання позитивних емоцій);

7) утилітарне (як вищий прояв нозофільної реакції - пошук мотиву хвороби для отримання співчуття, надлишку уваги, матеріального зиску). 


\section{Інноватика у вихованні. Випуск 14. 2021.}

У цьому випадку хвора людина може вдаватись до агравації (свідомого або несвідомого перебільшення існуючих симптомів) або симуляції неіснуючого захворювання) (Bagayogo, Interian, \& Escobar, 2013; Barsky, 2016).

Хронічні соматичні захворювання надалі можуть призводити до розвитку психосоматичних розладів. Психоемоційні розлади значно швидше виникають при хронічних захворюваннях 3 перебігом середнього ступеня тяжкості і посилюють психосоматичну симптоматику. Хронічні захворювання 3 тяжким перебігом (наприклад, гіпертіреоз) навіть після досягнення ремісії призводять до подальшої дезадаптації юнаків та підлітків, вимагають тривалого курсу реабілітації та відповідної психокорекції (Barsky, 2016).

Дезадаптація та зміна життєвого стереотипу проявляється у підлітків найперше у вигляді астено-невротичного синдрому, вегетативних розладів i, як результат, зниження успішності. Ці симптоми швидко виснажують підлітків, що призводить до зриву компенсаторних механізмів адаптації в соціумі та виникнення психопатологічних та сомато-вегетативних розладів.

Хронічне соматичне захворювання впливає на психічні та нервові функції як безпосередньо, так і через рефлекторні реакції в організмі (зміни кровопостачання, м'язового тонусу у вигляді спазмів, дискінезій, секреторних порушень), викликає патологічні імпульси від інтерорецепторів (відчуття стиснення, напруги, болю) 3 появою вторинних психоемоційних розладів, підсилених усвідомленням хвороби та їі можливих наслідків (Barsky, 2016).

Для дослідження впливу хронічних захворювань на психоемоційний стан застосовують два підходи. Перший полягає в спостереженні неспецифічної дії на людину, яка супроводжує кожне захворювання або фізичний дефект, другий - у спостереженні специфічної дії хронічного захворювання або дефекту. Перший виявляє деякі психоемоційні та психосоціальні проблеми в осіб 3 хронічними захворюваннями (зміну самооцінки, проблеми в спілкуванні 3 однолітками та ін.); другий дозволяє краще оцінити потенційний вплив хронічного захворювання на людину в кожному окремому випадку, з'ясувати специфічні фактори ризику (Винника та Вітенко, 2006).

Мета дослідження - визначити основні завдання та виокремити пріоритетні напрями психологічної корекції 3 юнаками та підлітками; встановити особливості психоемоційного стану, розладів особистості та поведінкових реакцій юнаків і підлітків з хронічними захворюваннями внутрішніх органів; розробити пропозиції, що допоможуть зменшити негативний вплив соматичної патології на психоемоційний стан.

Результати дослідження. При обстеженні 320 осіб віком від 14 до 20 років проведено узагальнення результатів обстеження за допомогою клініко-анамнестичног, клініко-психопатологічного, психо- 


\section{Інноватика у вихованні. Випуск 14. 2021.}

діагностичного та статистичного методів, що дало можливість 3'ясувати домінуючі соматичні та психологічні наслідки хронічних захворювань.

Соматичні наслідки:

1) функціональні та морфо-функціональні порушення внутрішніх органів (серцево-судинної та дихальної систем, шлунково-кишкового тракту);

2) розлади органів слуху або зору (амбліопія, міопія, астигматизм, приглухуватість);

3) побічні наслідки медикаментозного лікування чи оперативних втручань;

4) повторні загострення хронічних захворювань.

Психоемоційні наслідки:

1) функціональні церебральні розлади (порушення сну, астеноневротичний, обсесивно-фобічний та депресивний синдроми);

2) змінене переживання своєї особистості і поведінки;

3) важкість в комунікації та адаптації в соціальному середовищі.

У процесі дослідження 3'ясовано, що хронічні соматичні захворювання 3 тривалим перебігом вже в юнацькому віці призводять до специфічних та неспецифічних психологічних наслідків. Серед неспецифічних ми спостерігали фобічні прояви, обсесивні та депресивні прояви $з$ тривожністю.

У результаті проведеного дослідження у $80 \%$ осіб (n=256) спостерігається замкнутість, небажання розкривати свої проблеми та переживання, емоційне збіднення. Крім того, у переважної кількості осіб $(\mathrm{n}=308, \quad 96,3 \%) \quad 3$ діагностованими хронічними соматичними захворюваннями, зафіксовано наявність розладів особистості та психоповедінкових реакцій: сповільнення психічної активності, редукція захоплень, інстинктів та зміни настрою.

Сповільнення психічної активності було виражене в різному ступені: від підвищеної виснажливості і пасивності при астенічному синдромі $(\mathrm{n}=268,83,8 \%)$ до іпохондрії - при астено-депресивному $(\mathrm{n}=11,3,4 \%)$. В осіб з астенічним синдромом проявлявся стан нервово-психічної слабкості, зниження тонусу психічних процесів і сповільння відновлення сил, швидка втомлюваність під час навчання ще в першій половині навчального дня, нездатність до тривалої розумової і фізичної напруги. Настрій таких осіб був дуже лабільним упродовж дня, з елементами істероїдної капризності в осіб жіночої статі, незадоволенням або роздратуванням.

При дослідженні психоемоційного стану юнаків і підлітків 3 хронічною соматичною патологією астенічний синдром частіше проявлявся після перенесених гострих респіраторних захворювань (ГРВI, грипу, синуситу), при зловживанні палінням, кавою. При перенесених повторних ГРВІ спостерігалася більш виражена астенія з пасивністю та розвитком апатії.

Зміна захоплень і потягів проявлялися у небажанні займатись раніше улюбленими справами $(\mathrm{n}=154,48,1 \%)$, зниженні статевого потягу $(\mathrm{n}=212$, 


\section{Інноватика у вихованні. Випуск 14. 2021.}

$66,3 \%)$, підвищенні або зниженні апетиту ( $\mathrm{n}=168,52,5 \%)$. Інколи помітною також була дисоціація з підвищеним одним і зниженими іншими потягами.

Через 12-18 міс. від початку дослідження у 27\% юнаків із хронічною соматичною патологією астенічний синдром трансформувався в неврастенічний. Підвищена психічна виснажливість в таких осіб нерідко поєднувалася 3 надмірною збудливістю i загальною гіперестезією, дратівливістю, постійним відчуттям внутрішньої напруги; з'являлися дріб'язкові непорозуміння 3 колегами, родичами, інколи 3 неадекватною бурхливою реакцією підлітка на фоні супутніх цефалгій на зразок головного болю напруги, порушення сну, сомато-вегетативних розладаів (пітливості, серцебиття, кардіалгій, абдоміналгій та сенестопатій в різних ділянках тіла).

87,2\% (n=279) осіб мали різного ступеня дезадаптацію зі змінами життєвого стереотипу, невиразними супутніми когнітивними розладами: погіршення пам'яті, зниження концентрації уваги та сповільнення сприйняття нової інформації. У $2,4 \%$ осіб фіксували настирливість (обсесії) та фобії. Ці симптоми не призводили до порушення способу життя внаслідок поступового пристосування до фобій та уникнення ситуацій, в яких виникає страх. У 4-х осіб виявили особистісну тривожність із утрудненням прийняття будь-яких рішень.

Під час дослідження психоемоційного стану осіб з хронічною соматичною патологією в 3,4\% випадків була виявлена депресивна симптоматика 3 сенестопатіями (неприємними відчуттями в ділянці серця), цефалгіями або абдоміналгіями без морфо-функціональних змін при додатковому медичному обстеженні. У таких осіб виявляли депресивно змінене сприйняття навколишнього світу з відсутністю бажань до отримання задоволень і розваг, спостерігалося нерозуміння жартів, спотворене сприйняття власної особистості iз заниженою самоооцінкою. Тестуванням у таких осіб було виявлено сповільнення асоціативних процесів, звуження кола інтересів: відсутність інтересу до подій у світі і в батьківській сім'ї. Разом з ідеаторним спостерігалося і рухове гальмування у вигляді сповільнення і невпевнених дій, одноманітності жестів; сумний вираз обличчя, сповільнена і тиха мова, психоемоційні розлади у вигляді емоційної лабільності, сенситивності, інколи - образливості, підозрілості та настороженості (n=2).

Маючи різні соматичні захворювання, в таких юнаків і підлітків проявлялися специфічні, характерні тільки для них психологічні прояви. Зокрема, в осіб, 3 серцево-судинними захворюваннями в анамнезі (перенесений в дитинстві міокардит, вроджені вади серця, аритмії) були виявлені помірно виражені форми особистісних реакцій. Юнаки із вродженими вадами серця відчували себе стигматизованими: у них періодично виникав страх за майбутне, який вони намагались компенсувати завдяки високим досягненням у навчанні.

В осіб 3 порушеннями серцевого ритму нерідко увага була зосереджена на роботі власного серця 3 наступним виникненням переживань і страхів про його можливу «зупинку». Ці симптоми мали 


\section{Інноватика у вихованні. Випуск 14. 2021.}

тенденцію до посилення в нічний час з розвитком інсомнії. 3 часом в таких осіб з'являлося негативне ставлення до активної діяльності 3 появою тривожно-депресивних симптомів.

При обстеженні юнаків з хронічними захворюваннями нирок у понад $2 / 3$ випадків виявляли астенічний синдром, порушення сну, зниження працездатності, періодично пригнічений настрій, сомато-вегетативні порушення (коливання тиску, пітливість, мерзлякуватість, біль в попереку).

Психосоматичні розлади при ураженні органів шлунково-кишкового тракту проявлялися найчастіше у вигляді астено-невротичного синдрому, загострення характерологічних рис та акцентуації особистості. При тривалому перебігу захворювання спостерігалося виснаження психічних функцій (психастенія), розсіяність, сенситивність, емоційна лабільність, рідше - іпохондрія з фіксацією на власних переживаннях.

Висновки i перспективи подальших досліджень. На основі отриманих даних були визначені основні завдання психологічної корекції в юнацькому та підлітковому віці при хронічних соматичних захворюваннях:

1) підтримка загально-соматичного лікування;

2) психологічна підтримка;

3) корекція психологічних та емоційних порушень;

4) моніторинг за перебігом психосоматичних розладів;

5) профілактика загострень соматичного захворювання;

6) д допомога в досягненні психосоціальної адаптації і реінтеграції;

7) тривала та безперервна реабілітація.

При проведенні психокорекції осіб 3 хронічними соматичними захворюваннями максимальна ефективність досягається у співпраці психолога, психотерапевта 3 юнаком та його близькими (родичами). До того ж цьому основним завданням проведення психокорекції $\epsilon$ психологічна підтримка юнака/підлітка та сприяння психосоціальній адаптації. Слід сформувати дружні відносини 3 підлітком, аби краще зрозуміти його психологію та сімейну ситуацію. Після проведення діагностики та отримання інформації про психологічний стан можна проводити як індивідуально-орієнтовану, так і групову психотерапію. Методики психокорекції можуть застосовуватись як в комбінації, так і самостійно (психодинамічна, когнітивно-поведінкова терапія, клієнтцентровані та глибинно-психологічні методи, методи релаксації, гіпнозу та аутотренінгу). Окрім індивідуальної психокорекції ефективним може бути групова та сімейна психотерапія.

Для адекватного керівництва та моніторингу психокорекції, досягнення емоційного контакту, допомоги соціальної реадаптації необхідне також консультування близьких родичів і соціального оточення юнака (підлітка) із соматичних та педагогічно-психологічних питаннях, планування регулярних коротких візитів пацієнта до лікаря та психолога (психотерапевта). Розвиток емпатії і психоемоційна підтримка родичами та друзями є вкрай важливими для емоційної стабільності юнака/підлітка. 


\section{Інноватика у вихованні. Випуск 14. 2021.}

Психологічниий супровід, контроль за поведінковими реакціями підлітка, моніторинг динаміки симптомів сприяе прискоренню соціальної реадаптації після загострення хронічних соматичних захворювань, відновленню адекватної фізичної активності та навчальних здібностей, аналіз та узагальнення чого й стане основою для наступних досліджень.

\section{СПИСОК ВИКОРИСТАНИХ ДЖЕРЕЛ}

Винника М., Вітенко І. (ред.). (2006). Основи психодинамічної діагностики $i$ nсихотерапії. Навчально-метод. посібник. Івано-Франківськ: Місто НВ. 172 с.

Капська А. (ред.). (2003). Соціально-педагогічна робота з дітьми та молоддю 3 функиіональними обмеженнями. Навчально-метод. посібник для соціальних працівників і соціальних педагогів. Київ: ДЦССМ. 168 с.

Фетискин Н., Козлов В., Мануйлов, Г. (2002). Соииально-психологическая диагностика развития личности и мальех груn. Москва.: Изд. Института Психотерапии. $391 \mathrm{c.}$

Alonso J., Angermeyer M. C., Bernert S., Bruffaerts R., Brugha T. S., Bryson H., ... European Study of the Epidemiology of Mental Disorders (ESEMeD) Project. Disability and quality of life impact of mental disorders in Europe: results from the European Study of the Epidemiology of Mental Disorders (ESEMeD) project. Acta Psychiatrica Scandinavica. Supplementum. 2004. Vol. 420. P. 38-46.

Bagayogo I. P., Interian A., \& Escobar J. I. Transcultural aspects of somatic symptoms in the context of depressive disorders. Advances in Psychosomatic Medicine. 2013. Vol. 33. P. 64-74. DOI: 10.1159/000350057. Epub 2013 Jun 25.

Barsky A. J. Assessing the New DSM-5 Diagnosis of Somatic Symptom Disorder. Psychosomatic Medicine. 2016. Vol. 78, issue 1. P. 2-4. DOI: 10.1097/PSY.0000000000000287.

Eurenius E., Brodin N., Lindblad St. (2007). Predicting physical activity and general health perception among patients with rheumatoid arthritis / E. Eurenius, N. Brodin, St. Lindblad // Journal of rheumatology Vol. 34, No 1. P. 10-15.

Wegner P. Erstinterview; in Handbuch Psychoanalytischer Grundbegriffe, Kohlhammer, Stuttgart, 2000. - S.170-175.

\section{REFERENCES}

Vynnyka M., Vitenko I. (red.). (2006). Osnovy psykhodynamichnoi diahnostyky i psykhoterapii. [Fundamentals of psychodynamic diagnosis and psychotherapy]: Navchalno-metod. posibnyk. Ivano-Frankivsk: Misto NV. 172 s. [in Ukrainian].

Kapska A. (red.). (2003). Sotsialno-pedahohichna robota z ditmy ta moloddiu z funktsionalnymy obmezhenniamy [Socio-pedagogical work with children and youth with functional limitations]: Navchalno-metod. posibnyk dlia sotsialnykh pratsivnykiv i sotsialnykh pedahohiv. Kyiv: DTsSSM. 168 s. [in Ukrainian].

Fetiskin N., Kozlov V., Manuilov, G. (2002). Sotsialno-psikhologicheskaya diagnostika razvitiya lichnosti $\mathrm{v}$ malykh hrup. [Socio-psychological diagnosis of personality development and small groups]. Moskva.: Izd. Instituta Psikhoterapii. 391 s.[in Russian].

Alonso J., Angermeyer M. C., Bernert S., Bruffaerts R., Brugha T. S., Bryson H. (2004) European Study of the Epidemiology of Mental Disorders (ESEMeD) Project. Disability and quality of life impact of mental disorders in Europe: results from the European Study of the Epidemiology of Mental Disorders (ESEMeD) project. Acta Psychiatrica Scandinavica. Supplementum. Vol. 420: 38-46. [in English].

Bagayogo I. P., Interian A., \& Escobar J. I. (2013) Transcultural aspects of somatic symptoms in the context of depressive disorders. Advances in Psychosomatic Medicine. Vol. 33: 64-74. DOI: 10.1159/000350057. [in English]. 
Barsky A. J. (2016) Assessing the New DSM-5 Diagnosis of Somatic Symptom Disorder. Psychosomatic Medicine. Vol. 78, issue 1: 2-4. DOI: 10.1097/PSY.0000000000000287. [in English].

Eurenius E., Brodin N., Lindblad St. (2007) Predicting physical activity and general health perception among patients with rheumatoid arthritis / E.Eurenius, N.Brodin, St.Lindblad // Journal of rheumatology Vol. 34, No 1. P. 10-15. [in English].

Wegner P. (2000) Erstinterview; in Handbuch Psychoanalytischer Grundbegriffe, Kohlhammer, Stuttgart: 170-175. [in German].

\title{
VARIABLE INFLUENCE OF CHRONIC SOMATIC PATHOLOGY ON THE PSYCHOEMOTIONAL STATE OF YOUNG MEN AND ADOLESCENTS IN THE LEARNING PROCESS
}

\author{
Viacheslav Hrubliak \\ Candidate of Medical Sciences, Associate Professor \\ Kamianets-Podilskyi Ivan Ohiienko National University, \\ Kamianets-Podilskyi, Ukraine \\ ORCID: 0000-0001-8690-4227 \\ e-mail:sladoc15@gmail.com
}

Abstract. The article is devoted to elucidating the negative impact of somatic pathology on the psycho-emotional state of adolescents and young people, the priority areas of psychological correction. This study is aimed at studying the impact of chronic diseases on the psychological state and overall personality development of young men and adolescents, changing behavior and perception, and finding out the dominant somatic and psychological consequences in the learning process. The main tasks and directions of psychocorrective work with young men and adolescents with chronic somatic diseases were identified. The necessity of deepening the cognitive processes of adolescents, correcting behavior and psychoemotional development is confirmed; improving the skills of emotional and personal self-regulation, career guidance, communication skills and communicative competence, worldview attitudes. Based on an empirical study, priority areas of psychocorrective work with young men and adolescents are identified, and proposals are developed to reduce the negative impact of somatic pathology on their psychoemotional state. It is necessary to conduct both individual-oriented and group psychotherapy. When conducting psychological correction, various techniques can be used both in combination and independently (psychodynamic, cognitive-behavioral therapy, client-centered methods, deep psychological methods, methods of relaxation, hypnosis and self-training, etc.). In addition to individual psychocorrection of adolescents and young people, group and family psychotherapy can be effective. Particular importance in the social readaptation of adolescents and young people, the restoration of physical activity and learning abilities is given to psychocorrection, counseling, achieving a certain level of empathy, psychoemotional support, support and dynamic monitoring of symptoms after exacerbation of chronic somatic diseases.

Keywords: somatic diseases, psychocorrectional work, readaptation.

Стаття надійшла до редакиіï 24. 09. 2021 р. 